\title{
Changes of progesterone content of rat uterine flushings in relation to serum concentrations of progesterone during the oestrous cycle
}

\author{
P. J. Bonnamy, A. Benhaim and P. Leymarie \\ Laboratoire de Biochimie, CNRS URA 609, CHU Côte de Nacre, 14032 Caen, France
}

\begin{abstract}
Summary. Uterine fluid was collected from four-day cyclic rats at each stage of the oestrous cycle and assayed for progesterone and protein content. Progesterone was determined by radioimmunoassay either after ethanol (or $2.5 \% \mathrm{NaOH}$ ) denaturation of proteins from uterine flushings ('total' progesterone) or without protein denaturation ('ether-extractable' progesterone). The amount of 'ether-extractable' progesterone in the lumen was constant from metoestrus to pro-oestrus $(340 \mathrm{pg}$ per uterus) but lower in oestrus ( $200 \mathrm{pg}$ per uterus). However, 'total' progesterone content of uterine fluid was subject to cyclic variations and was highest in dioestrus $(890 \mathrm{pg}$ per uterus) and lowest in oestrus (350 pg per uterus), in contrast to serum progesterone which is lowest in dioestrus and highest in oestrus. Protein content of uterine flushings peaked to $780 \mu \mathrm{g}$ per uterus in pro-oestrus then fell to about $140 \mu \mathrm{g}$ per uterus until the end of the oestrous cycle. Changes in protein content of the lumen were followed by qualitative variations since the mean amount of 'bound' progesterone ('total' progesterone minus 'ether-extractable' progesterone) released per milligram of denatured lumen protein rose from $1.8 \mathrm{pmol}$ in pro-oestrus to $18.2 \mathrm{pmol}$ in dioestrus. The changes of luminal 'bound' progesterone during the oestrous cycle suggest that progesterone binding to luminal proteins could be an important modulator of progesterone action in rat uterus. Moreover, the variations in progesterone content of the lumen, irrespective of serum progesterone concentrations, are consistent with the hypothesis that progesterone synthesis occurs in the uterus.
\end{abstract}

Keywords: progesterone; uterine flushings; oestrous cycle; rat

\section{Introduction}

The composition of uterine fluid is particularly important for the understanding of reproductive processes. The uterine fluid constitutes the natural environment in which many events leading to the establishment of pregnancy occur (sperm ascent and capacitation, blastocyst growth and implantation).

Specific proteins are synthesized and secreted within the uterine lumen in response to ovarian steroids and considerable efforts have been made to analyse the protein composition of uterine fluid for a large variety of species in different hormonal conditions (Aitken, 1979; Bell, 1988). However, the origin and amount of steroids present in luminal fluid have been poorly explored, especially in rodents. Previous studies have shown selective concentrations of particular steroids in uterine lumen relative to plasma or serum (Eiler et al., 1977; Khan-Dawood \& Dawood, 1984; Zavy et al., 1984; Stone et al., 1986). Among these steroids, progesterone is of particular interest and its role in the histological and biochemical differentiation of endometrium for successful establishment of pregnancy is well known (Psychoyos, 1973; Glasser \& McCormack, 1982). 
We investigated the variations in progesterone content of rat uterine lumen throughout the four-day oestrous cycle. In rabbits, changes in progesterone concentrations in uterine washings have been associated with changes in uterine fluid protein content (Fowler et al., 1977), including those uterine specific proteins that bound progesterone with high specificity and affinity (Beato, 1976; Miele et al., 1987). We, therefore, measured the amount of progesterone released after denaturation of the luminal proteins of rats.

\title{
Materials and Methods
}

\begin{abstract}
Animals
Sprague-Dawley female rats, 3-4 months old, were housed individually under controlled temperature $\left(22 \pm 1^{\circ} \mathrm{C}\right)$ and photoperiod (lights on between $05: 00 \mathrm{~h}$ and 19:00 h) and the vaginal smears were recorded daily. Only rats exhibiting at least two consecutive four-day cycles were used. After staging, animals were killed by decapitation between $14: 00 \mathrm{~h}$ and 16:00 $\mathrm{h}$.
\end{abstract}

\section{Collection of sera and uterine washings}

Blood from each animal was collected at the time of decapitation and centrifuged at $4^{\circ} \mathrm{C}$ for $10 \mathrm{~min}$ at $1500 \mathrm{~g}$. Serum was collected and kept at $-20^{\circ} \mathrm{C}$ for subsequent progesterone determination.

Uterine horns were exposed by laparotomy, dissected free from connective tissues in situ, clamped at both ends and rinsed in sterile MEM (Minimum Essential Medium, Eurobio, Paris, France) pH 7.4 containing Earle's salts, $\mathrm{NaHCO}_{3}\left(2 \cdot 2 \mathrm{~g} \mathrm{l}^{-1}\right)$, L-glutamine $\left(2 \mathrm{mmol} \mathrm{l}^{-1}\right)$ and gentamycin sulphate $\left(60 \mu \mathrm{g} \mathrm{ml}^{-1}\right)$. Then $1 \mathrm{ml}$ sterile medium was gently injected with a fine needle into each horn at the uterotubal junction. The washing was collected by gravity at the cervical end of the uterine horn. All these operations took less than $10 \mathrm{~min}$ per animal The collected washing was then centrifuged at $1200 \mathrm{~g}$ for $15 \mathrm{~min}$ at $4^{\circ} \mathrm{C}$. The supernatant was collected and stored at $-20^{\circ} \mathrm{C}$ until assayed for progesterone and protein content. Any washings contamined with blood were discarded.

\section{Progesterone determinations}

'Ether extractable' progesterone, i.e. unbound and bound to protein with a low affinity, was extracted twice by diethyl ether (Merck France, Nogent sur Marne) from uterine flushings and serum samples and measured by radioimmunoassay using a highly specific antibody (Biomérieux, Lyon, France. The anti-progesterone serum crossreacted significantly only with deoxycortisone $(6 \cdot 6 \%)$, (5 $\alpha$-dihydroprogesterone $(3 \cdot 9 \%), 5 \beta$-dihydroprogesterone $(2.6 \%)$ and $6 \beta$-hydroprogesterone $(2 \cdot 1 \%)$. The sensitivity of the assay was $10 \mathrm{pg}$ per tube. The intra- and interassay coefficients of variation were less than $10 \%$.

'Total' progesterone in luminal fluid was defined as that obtained after denaturation of proteins from uterine washing and further extraction with diethyl ether. It was measured after precipitation of an aliquot of each sample with ethanol (Merck, $6 \mathrm{vol}: 1 \mathrm{vol}$ of sample). After overnight precipitation of proteins at $4^{\circ} \mathrm{C}$, the sample was centrifuged at $3000 \mathrm{~g}$ for $15 \mathrm{~min}$ at $4^{\circ} \mathrm{C}$. The pellet was kept for further determination of protein content. The supernatant was evaporated to dryness with a Speed-Vac concentrator (Savant Instruments Inc., Farmingdale, NY), resuspended in 0.1 mol phosphate buffered-saline $1^{-1}, \mathrm{pH} 7 \cdot 4$, containing $0.5 \%$ bovine serum albumin (BSA fraction $\mathrm{V}$, Sigma) and extracted twice with diethyl ether. The amount of 'total' progesterone was then determined by radioimmunoassay. 'Bound' progesterone was estimated by the difference between 'total' and 'ether-extractable' progesterone. Similar amounts of 'bound' progesterone in uterine flushing were obtained after ethanol treatment and after protein denaturation by $2.5 \% \mathrm{NaOH}$ as previously described for progesterone-binding globulin in guinea-pigs (Challis et al., 1971).

The specificity of the progesterone assay was further verified by steroid determination after celite chromatography (Abraham et al., 1972) of 16 different sera and 16 different uterine washings collected at the different stages of the oestrous cycle. The recovery of radiolabelled progesterone added to samples and eluted from celite columns was $90.9 \pm 0.4 \%$. Values of progesterone measured after chromatography and expressed as a percentage of those determined without purification were (mean \pm SEM): $91.6 \pm 6.3$ (serum progesterone); $99.6 \pm 4.7$ ('ether-extractable' progesterone in uterine washing) and $93 \cdot 7 \pm 6 \cdot 2$ ('bound' progesterone in uterine washing).

\section{Protein determination}

The protein pellet obtained after overnight precipitation of washings by ethanol was resuspended in $0.1 \mathrm{~mol} \mathrm{NaOH} l^{-1}$ and the amount of protein was determined by a protein-dye binding method (Bradford, 1976) with BSA fraction $V$ as standard. 


\section{Histological examinations}

The integrity of the luminal epithelium after flushing was verified by histological examination of several horns that had been fixed in Bouin's fluid after flushing. Transverse sections were cut at random all along the uterine horn and stained with haematoxylin-eosin for light microscope examination.

\section{Statistical analysis}

One-way analysis of variance (ANOVA) was used for statistical comparisons.

\section{Results}

The amount of 'ether-extractable' progesterone in uterine flushing was found to be remarkably constant throughout the oestrous cycle (about $340 \mathrm{pg}$ per uterus), except in oestrus when its value was reduced to $200 \mathrm{pg}$ per uterus (Fig. 1a). However, total progesterone content showed pronounced cyclic variations during the oestrous cycle (Fig. la). The lowest value occurred during the day of oestrus ( $350 \pm 30 \mathrm{pg}$ per uterus), progesterone content then gradually increased to reach a peak $(890 \pm 110 \mathrm{pg}$ per uterus) during the day of dioestrus. These variations reflected high amplitude changes in 'bound' progesterone content of uterine washing.

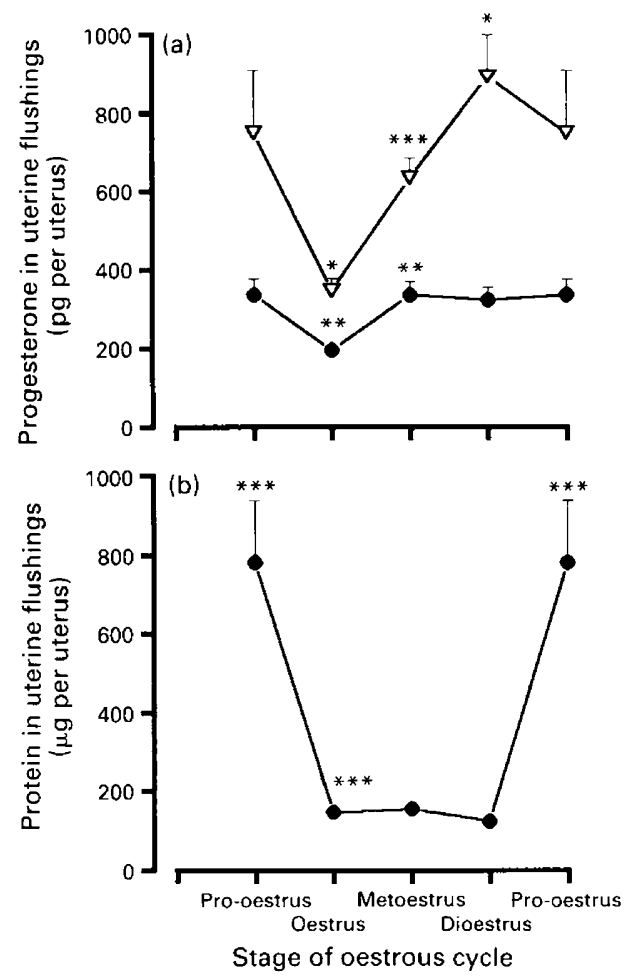

Fig. 1. Changes in (a) ether-extractable $(\bullet)$ and total $(\nabla)$ progesterone and (b) protein content of rat uterine washings during the oestrous cycle. Values are the mean \pm SEM of 15 pro-oestrus, 14 oestrus, 23 metoestrus and 17 dioestrus animals. ${ }^{* * *} P<0.001 ;{ }^{* *} P<0 \cdot 01$; ${ }^{*} P<0.05$ compared with the preceding stage of the oestrous cycle.

Changes in content of 'bound' progesterone were not accompanied by simultaneous variations in total protein content of the lumen. The total protein content of the lumen peaked at pro-oestrus (780 $\pm 160 \mu \mathrm{g}$ per uterus), concomitantly with the ballooning of the uterine horns, then remained 
constant at about $140 \mu \mathrm{g}$ per uterus from oestrus to dioestrus (Fig. Ib). Although the total protein content of the lumen remained constant from oestrus to dioestrus, modifications of the bound fraction were observed (Table 1). The ratio bound progesterone : total progesterone rose significantly $(P<0.05)$ from $40-45 \%$ (from pro-oestrus to metoestrus) to $58 \%$ in dioestrus. Moreover, the amount of progesterone released per milligram denatured lumen protein was increased tenfold from pro-oestrus to dioestrus. However, whatever the stage of the oestrous cycle, there was no linear correlation between the amount of lumen protein and the content of 'bound' progesterone measured in the same sample.

Table 1. Changes in the 'bound' progesterone fraction in rat uterine flushings during the oestrous cycle

\begin{tabular}{|c|c|c|c|}
\hline $\begin{array}{l}\text { Stage of the } \\
\text { oestrous cycle }\end{array}$ & $\begin{array}{c}\text { Relative proportion } \\
(\% \text { of 'total' progesterone })^{a}\end{array}$ & $\begin{array}{r}\text { Amount of p } \\
\text { after denaturat } \\
\text { pmole per uterus }\end{array}$ & $\begin{array}{l}\text { sterone released } \\
\text { of luminal proteins } \\
\text { pmoles } \mathrm{mg}^{-1} \text { protein }\end{array}$ \\
\hline Pro-oestrus $(15)^{\mathrm{b}}$ & $43 \cdot 6 \pm 6 \cdot 2$ & $1.31 \pm 0.45$ & $1.83 \pm 0.47^{* * *}$ \\
\hline Oestrus (14) & $38.7 \pm 6.5$ & $0.48 \pm 0.09$ & $3.34 \pm 0.79$ \\
\hline Metoestrus (23) & $45 \cdot 0 \pm 4 \cdot 0$ & $0.95 \pm 0.13^{* *}$ & $6.93 \pm 0.86^{* *}$ \\
\hline Dioestrus (17) & $58.4 \pm 4.4^{*}$ & $1.81 \pm 0.35^{*}$ & $18 \cdot 20 \pm 4.00^{* *}$ \\
\hline
\end{tabular}

${ }^{\mathrm{a} M e a n} \pm$ SEM.

'Number of animals.

Significantly different from the value obtained in the preceding stage of the oestrous cycle. $\left({ }^{* * *} P<0 \cdot 001\right.$; $\left.{ }^{* *} P<0.01 ;{ }^{*} P<0.05\right)$.

Parallel determinations of serum progesterone concentration and content of progesterone in the lumen indicated that the latter was not dependent on the former, at all stages of the oestrous cycle except at pro-oestrus (data not shown) where the two parameters were highly correlated $(r=0 \cdot 82$, $P<0.01)$. Moreover, the mean amount of 'bound' progesterone, as well as 'total' progesterone, in the uterine lumen, was inversely related to serum progesterone during the oestrous cycle (Fig. 2).

Finally progesterone content of lumen and its variations did not seem to be the consequence of tissue damage by flushing. Histological examinations did not reveal any discernible damage to the uterine epithelium at any stage of the oestrous cycle.

\section{Discussion}

These results demonstrated that (i) the amount of progesterone in rat uterine lumen was about $1 \mathrm{ng}$; (ii) in rat uterine washings progesterone was present in two forms, 'ether extractable' and 'bound'; the relative proportions of which differed according to the stage of the oestrous cycle; and (iii) progesterone content of the lumen was subject to oestrous-cycle-related variations that were independent of circulating progesterone concentrations.

Assuming a uterine fluid volume of $500 \mu \mathrm{l}$ per uterus on the day of pro-oestrus and of about $50 \mu 1$ at the other stages of the oestrous cycle (Nequin et al., 1979), the mean concentrations of 'ether extractable' and 'total' progesterone in rat lumen varied respectively from $0.7 \mathrm{ng} \mathrm{ml}^{-1}$ (pro-oestrus) to $6.8 \mathrm{ng} \mathrm{ml}^{-1}$ (metoestrus) and from $1.5 \mathrm{ng} \mathrm{ml}^{-1}$ (pro-oestrus) to $18 \mathrm{ng} \mathrm{ml}^{-1}$ (dioestrus). The absence of correlation between circulating concentration and uterine lumen concentration of progesterone seems to be a general phenomenon among all species studied, during the oestrous cycle as well as in early pregnancy (Eiler et al., 1977; Khan-Dawood \& Dawood, 1984; Zavy et al., 1984; Stone et al., 1986).

Excluding the day of pro-oestrus, when luminal 'ether extractable' progesterone content was highly correlated with serum progesterone probably because of an increase in uterine vascular permeability, the amount of progesterone present in rat uterine lumen was independent of serum progesterone concentrations. The variations of luminal progesterone content could be related 


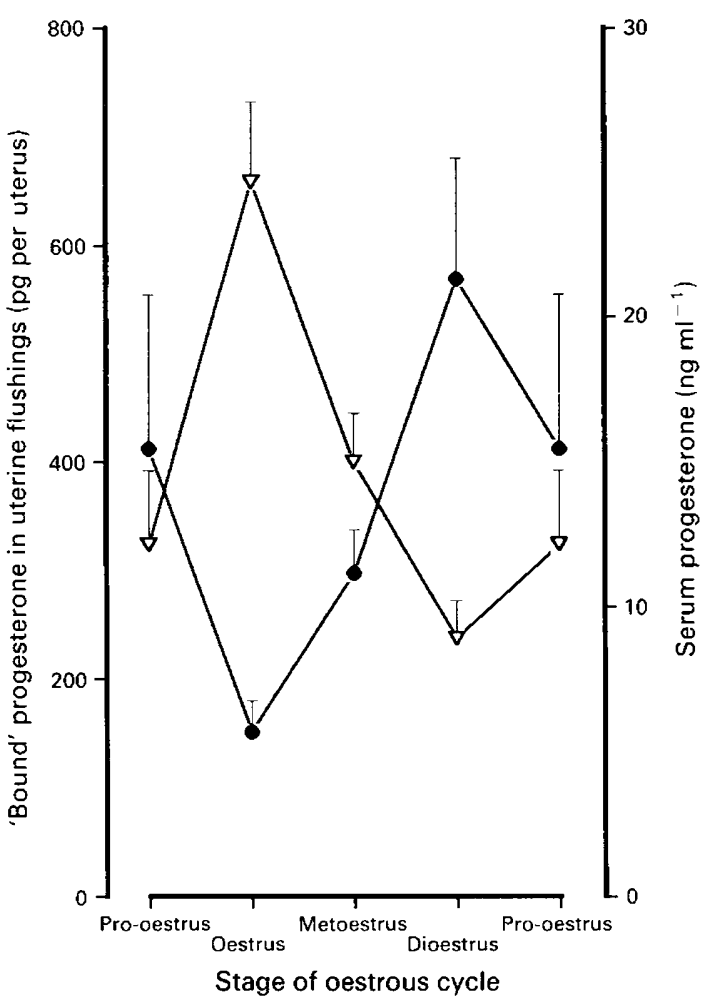

Fig. 2. Changes in luminal content of 'bound' progesterone $(-)$ and serum concentration of progesterone $(\nabla)$ during the oestrous cycle. Values are the mean \pm SEM of 15 pro-oestrus, 14 oestrus, 23 metoestrus and 17 dioestrus animals.

to phenomena observed in previous in vitro studies. Thus, during metoestrus the increase in progesterone content of lumen, either 'ether extractable' or 'total', is concomitant with (i) the emergence of in vitro luteinizing-hormone ( $\mathrm{LH}$ )-induced increase of progesterone uterine concentration (Bonnamy et al., 1989), (ii) increase of rat uterine $\mathrm{LH} /$ human chorionic gonadotrophin binding sites (Bonnamy et al., 1990) and (iii) the establishment of high amplitude LH pulses in serum (Fox \& Smith, 1985). During oestrus, the progesterone content of the uterine lumen was at its lowest level probably because of concomitant high progesterone catabolism previously described in vitro (Bonnamy et al., 1989). Finally, in dioestrus, the marked increase of binding of progesterone to luminal proteins could be responsible for a sharp decrease in endogenous progesterone uterine catabolism observed in vitro (P. J. Bonnamy, A. Benhaim \& P. Leymarie, unpublished).

An increase in "bound' progesterone in lumen is concomitant with an increase of progesterone receptor concentration in the uterus (Vu Hai et al., 1978). The possibility that the increase in 'bound' progesterone content is at least partly due to cellular lysis and release of receptor-bound progesterone in washings consecutive to flushing cannot be excluded. However, if this occurs, it would have a minor influence for two reasons (i) the amount of luminal 'bound' progesterone in dioestrus is equal to half the progesterone binding capacity of the uterus (Vu Hai et al., 1978) and, (ii) flushing does not lead to any discernible damage to the uterine tissue, at any stage of the oestrous cycle.

Measurement of the parameter 'pmols progesterone released per $\mathrm{mg}$ denaturated luminal protein', shows that the nature or relative composition of lumen proteins in pro-oestrus differs significantly from that of the postovulatory period. It is clear that most luminal proteins detected 
on the day of pro-oestrus do not bind progesterone although the steroid is then at its second highest concentration in uterine lumen. However, the tenfold decrease, from dioestrus to pro-oestrus, in the amount of progesterone released per milligram denaturated luminal protein is not solely the consequence of the concomitant fivefold increase of protein content of lumen. The biochemical nature of progesterone-binding protein(s) is still unknown. The lack of correlation between the amount of 'bound' progesterone and protein content of lumen suggests that progesterone-binding protein(s) is (are) quantitatively a minor component of uterine fluid. Moreover, the need to denature luminal protein to measure progesterone by radioimmunoassay suggests that luminal proteins bind progesterone with a very high affinity similar to that of progesterone-binding globulin of guinea pigs (Challis et al., 1971) and higher than that of uteroglobin or corticosteroid-binding globulin (Westphal, 1986). Finally, contrary to uteroglobin (Miele et al., 1987), the enhancement of progesterone binding by rat luminal proteins is concomitant with the fall of serum progesterone concentrations.

The biological significance of luminal sequestering of progesterone molecules (blood-borne, or synthesized by the endometrium or both) into the steroid-protein complex at the end of the oestrous cycle is unknown. Several suggestions have been made.

First, the progesterone-protein complex could represent the active form of progesterone. Although free steroids can diffuse into cells, the steroid concentration of target cells could be increased if necessary by internalization of bound steroid, as previously shown for corticosteroidbinding globulin and sex-hormone-binding globulin (Rosner, 1990). This phenomenon would lead to an additional degree of specificity and control of progesterone action.

Second, the liganded luminal protein could be the active form of protein and could activate, after binding to membranes, a second messenger system in uterine target cells. For example, it has been demonstrated previously that liganded, but not unliganded, corticosteroid-binding globulin induces increase of cAMP content in MCF7 cells (Nakhla et al., 1988).

Third, the formation of the progesterone-protein complex could protect progesterone against catabolizing enzymes. The low amount of progesterone in the lumen at oestrus, in spite of high progesterone concentration in serum, could be the result of low amount of progesterone-binding proteins in uterine fluid. The fall in progesterone content in lumen from pro-oestrus to oestrus could facilitate sperm ascent and capacitation, events that are inhibited by high progesterone concentrations (Harper, 1988).

In summary, it appears that progesterone content of lumen does not reflect serum progesterone concentrations. Uterine progesterone synthesis induced by LH or increase of luminal progesteronebinding protein allow the uterus to alter luminal progesterone concentrations irrespective of circulating concentrations and could make the uterine fluid suitable for intra-uterine reproductive events. However, numerous questions remained unresolved about the nature of the protein(s) involved in progesterone binding and about the physiological roles of the different forms of progesterone in the lumen.

We are grateful to C. Marguerite and Y. Lamotte for their excellent technical assistance. The work was supported by a postdoctoral fellowship to P. J. Bonnamy by the Fondation pour la Recherche Médicale.

\section{References}

Abraham, G.E., Buster, J.E., Lucas, L.A., Corrales, P.C. \& Teller, R.C. (1972) Chromatographic separation of steroid hormones for use in radioimmunoassay. Analytical Letters 5, 509-517.

Aitken, R.J. (1979) Uterine proteins. In Oxford Review's of Reproductive Biology, Vol. 1, pp. 35I-382. Ed.

J. R. Clarke. Clarendon Press, Oxford.
Beato, M. (1976) Binding of steroids to uteroglobin. Journal of Steroid Biochemistry 7, 327-334.

Bell, S.C. (1988) Secretory endometrial/decidual proteins and their function in early pregnancy. Journal of Reproduction and Fertility, Supplement 36, 109-125.

Bonnamy, P.J., Benhaim, A. \& Leymarie, P. (1989) Human chorionic gonadotropin affects tissue levels 
of progesterone and cyclic adenosine 3',5'-monophosphate in the metestrus rat uterus in vitro. Biology of Reproduction 40, 511-516.

Bonnamy, P.J., Benhaim, A. \& Leymarie, P. (1990) Estrous cycle-related changes of high affinity luteinizing hormone/human chorionic gonadotropin binding sites in the rat uterus. Endocrinology 126, 1264-1269.

Bradford, M.M. (1976) A rapid and sensitive method for the quantitation of microgram quantities of protein utilizing the principle of protein-dye binding. Analytical Biochemistry 72, 248--254.

Challis, J.R.G., Heap, R.B. \& Illingworth, D.V. (1971) Concentrations of oestrogen and progesterone in the plasma of non-pregnant, pregnant and lactating guinea pigs. Journal of Endocrinology 51, 333-345.

Eiler, H., Bahr, J. \& Nalbandov, A.V. (1977) Ovarian steroids in the uterine lumen. I. Effect of $\mathbf{L H}$ injection and mating in rabbits. Biology of Reproduction 17, 459-464.

Fowler, R.E., Johnson, M.H., Walters, D.E. \& Eager, D.D. (1977) The progesterone content of rabbit uterine flushings. Journal of Reproduction and Fertility 50, 301-308.

Fox, S.R. \& Smith, M.S. (1985) Changes in the pulsatile pattern of luteinizing hormone secretion during the rat estrous cycle. Endocrinology 116, 1485-1492.

Glasser S.R. \& McCormack, S.A. (1982) Cellular and molecular aspects of decidualization and implantation. In Cellular and Molecular Aspects of Decidualization and Implantation, pp. 245-310. Eds H. M. Beier \& P. Karlson. Springer-Verlag, Berlin.

Harper, M. J. K. (1988) Gamete and ovum transport. In The Physiology of Reproduction, pp. 103-134. Eds E. Knobil \& J. Neill. Raven Press, New York.

Khan-Dawood, F.S. \& Dawood, M.Y. (1984) Implantation of the rabbit blastocyst: sequential changes in estradiol and progesterone and their receptors. American Journal of Obstetrics and Gynecology 150, $450-455$.
Miele, L., Cordella-Miele, E. \& Mukherjee, A.B. (1987) Uteroglobin: structure, molecular biology, and new perspectives on its function as phospholipase $A_{2}$ inhibitor. Endocrine Review's 8, 474-490.

Nakhla, A. M., Khan, M.S. \& Rosner, W. (1988) Induction of adenylate cyclase in a mammary carcinoma cell line by human corticosteroid-binding globulin. Biochemical and Biophysical Research Communication 153, 1012-1018.

Nequin, L.G., Alvarez, J. \& Schwartz, N.B. (1979) Measurement of serum steroid and gonadotropin levels and uterine and ovarian variables throughout 4-day and 5-day estrous cycles in the rat. Biology of Reproduction 20, 659-670.

Psychoyos, A. (1973) Hormonal control of ovoimplantation. Vitamins and Hormones 31, 201-256.

Rosner, W. (1990) The functions of corticosteroidbinding globulin and sex hormone-binding globulin: recent advances. Endocrine Reviews 11, 80-91.

Stone, B.A., Petrucco, O.M., Seamark, R.F. \& Godfrey, B.M. (1986) Concentration of steroid hormones, and of prolactin, in washings of the human uterus during the menstrual cycle. Journal of Reproduction and Fertility 78, 21-25.

Vu Hai, M.T., Logeat, F. \& Milgrom, E. (1978) Progesterone receptors in the rat uterus: variations in cytosol and nuclei during the oestrous cycle and pregnancy. Journal of Endocrinology 76, 43-48.

Westphal, V. (1986) Steroid-protein Interactions II. Springer-Verlag, Berlin.

Zavy, M.T., Vernon, M.W., Sharp, D.C. \& Bazer, F.W. (1984) Endocrine aspects of early pregnancy in pony mares: a comparison of uterine luminal and peripheral plasma levels of steroids during the estrous cycle and early pregnancy. Endocrinology 115, 214-219.

Received 7 August 1991 